\title{
KEMAMPUAN BATU APUNG SEBAGAI ADSORBEN PENYISIHAN LOGAM BESI (Fe) AIR TANAH
}

\author{
Suarni S. Abuzar, Tivany Edwin, Utami Langga Sari Hasibuan \\ Jurusan Teknik Lingkungan, Fakultas Teknik Universitas Andalas \\ Email: suarni_sa@ft.unand.ac.id
}

\begin{abstract}
ABSTRAK
Air tanah sebagai salah satu sumber air baku biasanya memiliki kandungan logam besi (Fe) yang relatif tinggi sehingga perlu diolah.. Salah satu alternatif pengolahan yang dapat dilakukan adalah adsorpsi. Salah satu material yang dapat digunakan sebagai adsorben adalah batu apung. Batu apung banyak terdapat di alam dan belum banyak dimanfaatkan, salah satunya di Sungai Pasak, Pariaman Timur. Sehubungan dengan itu perlu dilakukannya penelitian penyisihan Fe air tanah menggunakan batu apung sebagai adsorben. Tujuan penelitian ini adalah menganalisis kemampuan batu apung sebagai adsorben penyisihan Fe air tanah. Penelitian dilakukan secara batch dengan variasi dosis adsorben, waktu kontak, diameter adsorben, $\mathrm{pH}$ adsorbat dan konsentrasi adsorbat pada larutan artifisial dan sampel air tanah. Konsentrasi Fe diukur dengan Spektrofotometer Serapan Atom (SSA). Hasil penelitian menunjukkan, kondisi optimum penyisihan Fe pada larutan artifisial terjadi pada : dosis adsorben 0,03 g/l, waktu kontak 1 jam, diameter adsorben < $149 \mu \mathrm{m}$, pH adsorbat 5 dan konsentrasi adsorbat $15 \mathrm{mg} /$. Efisiensi penyisihan Fe pada larutan artifisial sebesar 91,25\% dengan kapasitas penjerapan 45,63 mg/g dan pada sampel air tanah sebesar 81,78\% dengan kapasitas penjerapan $40,41 \mathrm{mg} / \mathrm{g}$. Persamaan isoterm terpilih adalah isoterm Langmuir dengan kapasitas serapan maksimum Fe 38,43 mg/g. Dapat disimpulkan, penggunaan batu apung sebagai adsorben mampu menyisihkan Fe dengan baik.
\end{abstract}

Kata kunci: Air tanah, logam besi (Fe), adsorpsi, batu apung, batch

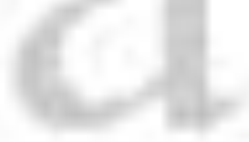

\section{ABSTRACT}

Groundwater as a source of raw water usually has a relatively high content of iron ( $\mathrm{Fe}$ ) so that needs be processed. One of alternative treatment that can be done is adsorption. One of teh material taht can be used as an adsorbent is pumice. Pumice is widely available in nature and have not been overly used, one of which Sungai Pasak, East Pariaman. This research aims to analyze the the capability of pumice as adsorbent of iron removal from ground water. This research was conducted in batches with variation of adsorbent dose, contact time, diameter of adsorbent, pH of adsorbate and concentration of adsorbate in artificial solution and groundwater samples. Concentration of iron were measured by Atomic Absorption Spectrophotometer (AAS). The results showed the optimum condition of iron removal in artificial solution occurs at adsorbent dose was $0,03 \mathrm{~g} / \mathrm{l}$, contact time was 1 hour, diameter of adsorbent was $<149 \mu \mathrm{m}$, pH of adsorbate was 5 and concentration of adsorbent was 15 ppm. The efficiency of iron removal in artificial solution was 91,25\% with uptake capacity was 45,63 $\mathrm{mg} / \mathrm{g}$ and in ground water samples was $81,78 \%$ with uptake capacity was $40,41 \mathrm{mg} / \mathrm{g}$. Selected isotherm equation is the Langmuir isotherm with maximum uptake capacity was 38,43 $\mathrm{mg}$ Fe/g. It can be concluded that the use of pumice as an adsorbent capable of iron removal well.

Keywords: ground water, iron (Fe), adsorption, pumice, batch 


\section{PENDAHULUAN}

Air tanah biasanya memiliki kandungan besi yang relatif tinggi. Kadar $\mathrm{Fe}$ dalam jumlah sedikit diperlukan untuk pembentukan sel darah merah, tetapi jika kadarnya terlalu besar dapat berdampak buruk bagi kesehatan manusia dan lingkungan. Oleh karena itu pada beberapa sumber air tanah harus dilakukan pengolahan terlebih dahulu sebelum digunakan (Effendi, 2003).

Salah satu pengolahan yang dapat digunakan untuk menyisihkan logam $\mathrm{Fe}$ dalam air tanah adalah Adsorpsi (Joko, 2010). Salah satu alternatif adsorben dengan biaya lebih rendah dan efektifitas lebih baik adalah batu apung (Somerville, 2007).

Batu apung adalah jenis batuan yang berwarna terang yang mengandung buih yang terbuat dari gelembung berdinding gelas dan biasanya disebut juga sebagai batuan gelas vulkanik silikat. Batu apung memiliki struktur yang berpori dan mengandung banyak sekali kapiler-kapiler yang halus, sehingga adsorbat akan teradsorpsi pada kapiler tersebut (Endahwati, 2011). Kemampuan batu apung sebagai adsorben telah diuji dalam beberapa penelitian, diantaranya dalam penyisihan arsenik dari sumber air minum dengan efisiensi penyisihan sebesar98\% (Heidari et.al, 2011) dan dalam penyisihan materi organik alami (NOM) dari air tanah dengan efisiensi penyisihan sebesar 90\% (Kitis et.al, 2007).

Sehubungan dengan hal perlu dilakukan penelitian untuk menganalisis penyisihan logam besi $(\mathrm{Fe})$ pada air tanah menggunakan adsorben batu apung dengan berbagai variasi kondisi untuk menentukan kondisi optimum.

Tujuan penelitian ini adalah menganalisis kondisi optimum kemampuan batu apung sebagai adsorben dalam penyisihan logam $\mathrm{Fe}$ air tanah, menganalisis perbedaan efisiensi penyisihan dan kapasitas penjerapan logam $\mathrm{Fe}$ pada larutan artifisial dan sampel air tanah, dan menentukan persamaan isoterm yang sesuai dengan penyisihan logam $\mathrm{Fe}$ menggunankan adsorben batu apung.

\section{METODOLOGI}

Sampel air sumur yang digunakan berasal dari Sumur Perumahan Penduduk Bandar Buat di
Kecamatan Lubuk Kilangan, Kota Padang yang memiliki kandungan logam $\mathrm{Fe}$ tinggi. Sampel dianalisis untuk mengetahui karakteristik awal sampel.

Penelitian ini dilakukan dalam skala laboratorium secara batch di Laboratorium Jurusan Teknik Lingkungan Universitas Andalas.

Peralatan yang digunakan dalam penelitian ini adalah sieve shaker, erlenmeyer $250 \mathrm{ml}$, neraca analitik (AND. HR-60), pH meter (Eutech Instruments, Ecoscan Hand-held Series), shaker (Wisd Laboratory Instrument, Wideshake SHD-2D), centrifuged (Hettich, EBA-21), dan Spektrofotometer Serapan Atom (SSA) (Rayleigh, WFX-320).

Pembuatan adsorben dilakukan dengan menghaluskan batu apung kering dengan cara ditumbuk hingga menjadi bubuk. Bubuk batu apung di ayak dengan sieve shaker dan diperoleh bubuk batu apung dengan diameter < $149 \mu \mathrm{m}, 149-210 \mu \mathrm{m}, 210-300 \mu \mathrm{m}, 300-600$ $\mu \mathrm{m}$ dan 600-710 $\mu \mathrm{m}$. Tahap akhir adalah mencuci bubuk batu dengan aquadest dan dikeringkan dengan temperatur kamar.

Percobaan optimasi menggunakan larutan artifisial $\mathrm{Fe}$ yang di peroleh dari pengenceran larutan induk Fe 100 mg/l. Konsentrasi larutan artifisial mewakili konsentrasi sampel asli.

Pada penelitian ini dilakukan dua kali percobaan optimasi yaitu pada konsentrasi $\mathrm{Fe}$ sama yaitu $15 \mathrm{mg} / \mathrm{L}$ dan pada konsentrasi $\mathrm{Fe}$ yang berbeda/divariasikan. Variasi parameter dan urutan percobaan pada percobaann optimasi dengan konsentrasi $\mathrm{Fe}$ sama dapat dilihat pada Tabel 1.

Optimasi pada konsentrasi Fe sama menggunakan variasi $\mathrm{pH}$, dosis, waktu kontak dan diameter sedangkan optimasi pada konsentrasi $\mathrm{Fe}$ berbeda dilakukan dengan memvariasikan $\mathrm{pH}$ dan konsentrasi serta menggunakan kondisi optimum dosis, waktu kontak dan diameter pada optimasi dengan konsentrasi Fe sama sebagai data konstan. Variasi parameter dan urutan percobaan pada optimasi pada konsentrasi $\mathrm{Fe}$ berbeda yang digunakan dapat dilihat pada Tabel 2 dan Tabel 3. 
Tabel 1. Variasi Parameter dan Urutan Percobaan Optimasi pada Konsentrasi Fe Sama

\begin{tabular}{|c|c|c|c|c|c|c|}
\hline \multirow[b]{2}{*}{ No } & \multirow{2}{*}{$\begin{array}{c}\text { Konsentrasi } \\
\text { Larutan } \\
\text { Standar } \\
(\mathrm{mg} / \mathrm{l})\end{array}$} & \multicolumn{4}{|c|}{ Parameter } & \multirow[b]{2}{*}{ Hasil } \\
\hline & & $\mathbf{p H}$ & $\begin{array}{c}\text { Dosis } \\
\text { Adsorben } \\
(\mathrm{gr} / \mathrm{l}) \\
\end{array}$ & $\begin{array}{c}\text { Waktu } \\
\text { Kontak (jam) }\end{array}$ & $\begin{array}{l}\text { Diameter } \\
\text { Adsorben } \\
\left(\mathbf{1 0}^{-3} \mathbf{~ m m}\right)\end{array}$ & \\
\hline \multirow{5}{*}{1} & \multirow{5}{*}{15} & 4 & 1 & 0,5 & $210-300$ & \multirow{5}{*}{$\begin{array}{c}\text { pH } \\
\text { Optimum }\end{array}$} \\
\hline & & 6 & 1 & 0,5 & $210-300$ & \\
\hline & & 7 & 1 & 0,5 & $210-300$ & \\
\hline & & 8 & 1 & 0,5 & $210-300$ & \\
\hline & & 10 & 1 & 0,5 & $210-300$ & \\
\hline \multirow{5}{*}{2} & \multirow{5}{*}{15} & \multirow{5}{*}{$\begin{array}{c}\mathrm{pH} \\
\text { Optimum }\end{array}$} & 0,03 & 0,5 & $210-300$ & \multirow{5}{*}{$\begin{array}{c}\text { Dosis } \\
\text { Optimum }\end{array}$} \\
\hline & & & 0,1 & 0,5 & $210-300$ & \\
\hline & & & 0,5 & 0,5 & $210-300$ & \\
\hline & & & 1 & 0,5 & $210-300$ & \\
\hline & & & 3 & 0,5 & $210-300$ & \\
\hline \multirow{5}{*}{3} & \multirow{5}{*}{15} & \multirow{5}{*}{$\begin{array}{c}\mathrm{pH} \\
\text { Optimum }\end{array}$} & \multirow{5}{*}{$\begin{array}{c}\text { Dosis } \\
\text { Optimum }\end{array}$} & 0,5 & $210-300$ & \multirow{5}{*}{$\begin{array}{c}\text { Waktu } \\
\text { Kontak } \\
\text { Optimum }\end{array}$} \\
\hline & & & & 1 & $210-300$ & \\
\hline & & & & 1,5 & $210-300$ & \\
\hline & & & & 2 & $210-300$ & \\
\hline & & & & 2,5 & $210-300$ & \\
\hline \multirow{5}{*}{4} & \multirow{5}{*}{15} & \multirow{5}{*}{$\begin{array}{c}\mathrm{pH} \\
\text { Optimum }\end{array}$} & \multirow{5}{*}{$\begin{array}{c}\text { Dosis } \\
\text { Optimum }\end{array}$} & \multirow{5}{*}{$\begin{array}{l}\text { Waktu Kontak } \\
\text { Optimum }\end{array}$} & $<149$ & \multirow{5}{*}{$\begin{array}{l}\text { Diameter } \\
\text { Optimum }\end{array}$} \\
\hline & & & & & $149-210$ & \\
\hline & & & & & $210-300$ & \\
\hline & & & & & $300-600$ & \\
\hline & & & & & $600-710$ & \\
\hline
\end{tabular}

Tabel 2. Variasi Parameter Percobaan Optimasi pada konsentrasi Fe berbeda

\begin{tabular}{clcc}
\hline No & Parameter & Satuan & Variasi \\
\hline 1. & Dosis adsorben & $\mathrm{g} / \mathrm{l}$ & 0,03 \\
\hline 2. & Waktu kontak & $\mathrm{Jam}$ & 1 \\
\hline 3. & $\begin{array}{l}\text { Diameter } \\
\text { adsorben }\end{array}$ & $\mu \mathrm{m}$ & $<149$ \\
\hline 4. & pH adsorbat & - & $4,5,6,7,8$ \\
\hline 5. & $\begin{array}{l}\text { Konsentrasi } \\
\text { adsorbat }\end{array}$ & $\mathrm{mg} / 1$ & 2,$5 ; 5 ; 10 ; 15 ; 20$ \\
\hline
\end{tabular}

Percobaan dilakukan dengan mencampur sampel dengan adsorben batu apung di dalam erlenmeyer, kemudian diaduk menggunakan shaker dengan kecepatan pengadukan 100 rpm. Setelah itu sampel dipisahkan dari padatan dengan sentrifuged. Sampel yang

telah selesai diberi perlakuan kemudian diukur konsentrasi logam $\mathrm{Fe}$ menggunakan alat Spektrofotometer Serapan Atom (SSA) sesuai dengan cara uji logam Fe menurut SNI 066989.4-2004.

Efisiensi penyisihan logam $\mathrm{Fe}$ dengan adsorben batu apung dihitung dengan persamaan (1).

$\% \mathrm{R}=\frac{\text { Cin }- \text { Cout }}{\text { Cin }} \times 100 \%$.
Dimana:

$\mathrm{R}=$ Penyisihan

$\mathrm{C}_{\mathrm{in}}=$ Konsentrasi ion logam pada larutan saat awal $(\mathrm{mg} / \mathrm{L})$

$\mathrm{C}_{\text {out }}=$ Konsentrasi ion logam pada larutan saat kesetimbangan $(\mathrm{mg} / \mathrm{L})$

Kapasitas penjerapan adsorben batu apung terhadap logam $\mathrm{Fe}$ dihitung dengan persamaan (2).

$\frac{\% \mathrm{R}}{100} \times \operatorname{Cin} \mathrm{X} \frac{\mathrm{V}}{\mathrm{m}}$

Dimana:

$\mathrm{R}=$ Penyisihan

$\mathrm{C}_{\mathrm{in}}=$ Konsentrasi ion logam pada larutan saat awal $(\mathrm{mg} / \mathrm{L})$

$\mathrm{V}=$ Volume larutan yang digunakan $(\mathrm{L})$

$\mathrm{M}=$ Berat adsorben yang digunakan (gr) 
Tabel 3. Urutan Percobaan Optimasi pada konsentrasi Fe berbeda

\begin{tabular}{|c|c|c|c|c|c|c|}
\hline No & $\begin{array}{c}\text { Dosis } \\
\text { Adsorben } \\
\text { (g/L) }\end{array}$ & $\begin{array}{c}\text { Waktu } \\
\text { Kontak } \\
\text { (jam) }\end{array}$ & $\begin{array}{l}\text { Diameter } \\
\text { Adsorben } \\
\quad(\mu \mathrm{m})\end{array}$ & Variasi pH & $\begin{array}{c}\text { Variasi } \\
\text { Konsentrasi } \\
\text { Adsorbat } \\
(\mathbf{m g} / \mathbf{l}) \\
\end{array}$ & Hasil \\
\hline \multirow{5}{*}{1} & \multirow{25}{*}{0,03} & \multirow{25}{*}{1} & \multirow{25}{*}{$<149$} & \multirow{5}{*}{4} & 2,5 & \multirow{5}{*}{$\begin{array}{l}\text { pH Optimum } \\
\text { terhadap } \\
\text { Konsentrasi }\end{array}$} \\
\hline & & & & & 5 & \\
\hline & & & & & 10 & \\
\hline & & & & & 15 & \\
\hline & & & & & 20 & \\
\hline \multirow{5}{*}{2} & & & & \multirow{5}{*}{5} & 2,5 & \multirow{5}{*}{$\begin{array}{l}\text { pH Optimum } \\
\text { terhadap } \\
\text { Konsentrasi }\end{array}$} \\
\hline & & & & & 5 & \\
\hline & & & & & 10 & \\
\hline & & & & & 15 & \\
\hline & & & & & 20 & \\
\hline \multirow{5}{*}{3} & & & & & 2,5 & \multirow{5}{*}{$\begin{array}{l}\text { pH Optimum } \\
\text { terhadap } \\
\text { Konsentrasi }\end{array}$} \\
\hline & & & & & 5 & \\
\hline & & & & 6 & 10 & \\
\hline & & & & & 15 & \\
\hline & & & & & 20 & \\
\hline \multirow{5}{*}{4} & & & & \multirow{5}{*}{7} & 2,5 & \multirow{5}{*}{$\begin{array}{l}\text { pH Optimum } \\
\text { terhadap } \\
\text { Konsentrasi }\end{array}$} \\
\hline & & & & & 5 & \\
\hline & & & & & 10 & \\
\hline & & & & & 15 & \\
\hline & & & & & 20 & \\
\hline \multirow{5}{*}{5} & & & & \multirow{5}{*}{8} & 2,5 & \multirow{5}{*}{$\begin{array}{l}\text { pH Optimum } \\
\text { terhadap } \\
\text { Konsentrasi }\end{array}$} \\
\hline & & & & & 5 & \\
\hline & & & & & 10 & \\
\hline & & & & & 15 & \\
\hline & & & & & 20 & \\
\hline
\end{tabular}

Persamaan isoterm Freundlich (Atkins, 1996):

$Q_{e}=K_{f} \cdot C_{e}{ }^{1 / n}$

Keterangan:

$Q_{e}=$ Kerapatan adsorpsi pada konsentrasi kesetimbangan $\mathrm{Ce}$ (mg adsorbat/g adsorben) atau (x/m)

$C_{e}=$ Konsentrasi akhir adsorbat dalam larutan $(\mathrm{mg} / \mathrm{L})$

$K_{f}=$ Tetapan Freundlich yang berhubungan dengan energi adsorpsi (L adsorben/mg adsorbat)

$n=$ Tetapan empiris yang bergantung pada beberapa faktor lingkungan dan harganya lebih besar dari 1

Bentuk linear persamaan isoterm Freundlich (Atkins, 1999):

$\log \left(\frac{x}{m}\right)=\log K+\frac{1}{n} \log C e$

Persamaan Isoterm Langmuir (Atkins, 1999): $\frac{x}{m}=\frac{\alpha \beta C_{e}}{1+\beta C_{e}}$

Keterangan:

(2.15)

$\mathrm{x}=$ Massa substansi yang diadsorp

$\mathrm{m}=$ Massa adsorben

$\mathrm{C}_{\mathrm{e}}=$ Konsentrasi akhir ion logam saat kesetimbangan

$\alpha=$ Penyisihan maksimum yang berhubungan dengan kejenuhan adsorben (kapasitas adsorpsi maksimum)

$\beta=$ Konstanta percobaan yang berhubungan dengan afinitas

Bentuk linear persamaan isoterm Langmuir (Atkins, 1999):

$\frac{C_{B}}{x / m}=\frac{1}{\alpha \beta}+\frac{1}{\alpha} C_{\theta}$

\section{HASIL DAN PEMBAHASAN}

\section{Analisa Pada Sampel}

Konsentrasi logam Fe pada sampel pada sebesar $14,75 \mathrm{mg} / \mathrm{l}$. Konsentrasi larutan 
artifisial disesuaikan dengan konsentrasi logam $\mathrm{Fe}$ pada sampel, dibulatkan menjadi $15 \mathrm{mg} / \mathrm{l}$.

Selain logam Fe, dilakukan analisa sampel terhadap kandungan beberapa logam lain yaitu logam seng $(\mathrm{Zn})$, logam tembaga $(\mathrm{Cu})$, logam mangan $(\mathrm{Mn})$ dan logam lainnya. Hasil analisa sampel dapat dilihat pada Tabel 4.

Tabel 4. Hasil Analisa Sampel

\begin{tabular}{lr}
\hline \multicolumn{1}{c}{ Parameter } & Konsentrasi sampel \\
\hline $\mathrm{pH}$ & 7,34 \\
\hline Temperatur $\left({ }^{\circ} \mathrm{C}\right)$ & 27,00 \\
\hline Logam $\mathrm{Fe}(\mathrm{mg} / \mathrm{l})$ & 14,75 \\
\hline Logam $\mathrm{Zn}(\mathrm{mg} / \mathrm{l})$ & 1,67 \\
\hline Logam $\mathrm{Cu}(\mathrm{mg} / \mathrm{l})$ & 0,51 \\
\hline Logam $\mathrm{Mn}(\mathrm{mg} / \mathrm{l})$ & 4,93 \\
\hline
\end{tabular}

Percobaan Optimasi pada konsentrasi Fe sama Pada Larutan Artifisial

Percobaan optimasi pada konsentrasi $\mathrm{Fe}$ samadilakukan dengan variasi $\mathrm{pH}$, dosis, waktu kontak dan diameter.

\section{Penentuan pH Adsorbat Optimum}

Variasi $\mathrm{pH}$ yaitu $4,6,7,8$, dan 10 dengan menggunakan dosis adsorben sebanyak 1 $\mathrm{g} / \mathrm{L}$, waktu kontak selama 0,5 jam dan diameter 210-300 $\mu \mathrm{m}$. Hasil percobaan optimasi variasi $\mathrm{pH}$ adsorbat dapat dilihat pada Gambar 1 dan Gambar 2.

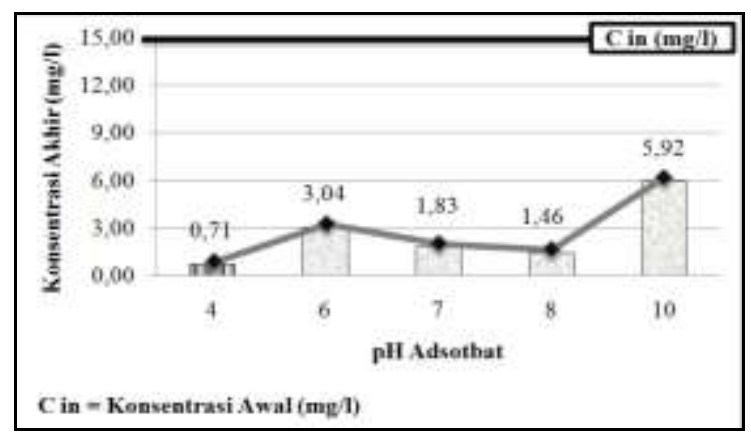

Gambar 1. Konsentrasi Akhir Fe Pada Variasi $\mathrm{pH}$

Penurunan konsentrasi logam $\mathrm{Fe}$ terbesar terjadi pada $\mathrm{pH} 4$ yaitu dari konsentrasi awal $15 \mathrm{mg} / \mathrm{l}$ turun menjadi $0,71 \mathrm{mg} / \mathrm{l}$ dengan efisiensi sebesar 95,28\% dan kapasitas penjerapan $1,43 \mathrm{mg} / \mathrm{g}$.

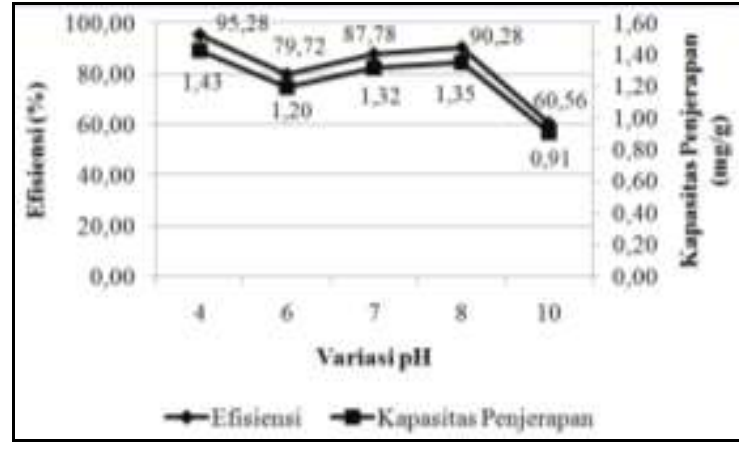

Gambar 2. Efisiensi dan Kapasitas Penjerapan Fe Pada Variasi pH

Dari hasil percobaan diperoleh bahwa penyisihan logam $\mathrm{Fe}$ terbesar terjadi pada pH 4 (asam) dan terkecil pada pH 10 (basa). Kondisi ini sesuai dengan pernyataan Khairi (2004), bahwa pada kondisi asam jumlah adsorbat yang teradsorp akan semakin besar tetapi pada kondisi basa jumlah adsorbat teradsorp menurun karena terbentuk endapan.

\section{Penentuan Dosis Adsorben Optimum}

Variasi dosis adsorben yaitu $0,03 \mathrm{~g} / \mathrm{L}, 0,1$ $\mathrm{g} / \mathrm{L}, \quad 0,5 \mathrm{~g} / \mathrm{L}, 1 \mathrm{~g} / \mathrm{L}$ dan $3 \mathrm{~g} / \mathrm{L}$ dengan menggunakan waktu kontak selama 0,5 jam, diameter adsorben 210-300 $\mu \mathrm{m}$ dan $\mathrm{pH}$ optimum yaitu $\mathrm{pH}$. Hasil percobaan optimasi dengan variasi dosis adsorben dapat dilihat pada Gambar 3 dan Gambar 4.

Penurunan konsentrasi logam $\mathrm{Fe}$ terbesar terjadi pada dosis $3 \mathrm{~g} / \mathrm{l}$ yaitu dari konsentrasi awal $15 \mathrm{mg} / \mathrm{l}$ turun menjadi $0,92 \mathrm{mg} / \mathrm{l}$ dengan efisiensi sebesar 93,89\% dan kapasitas penjerapan $0,47 \mathrm{mg} / \mathrm{g}$.

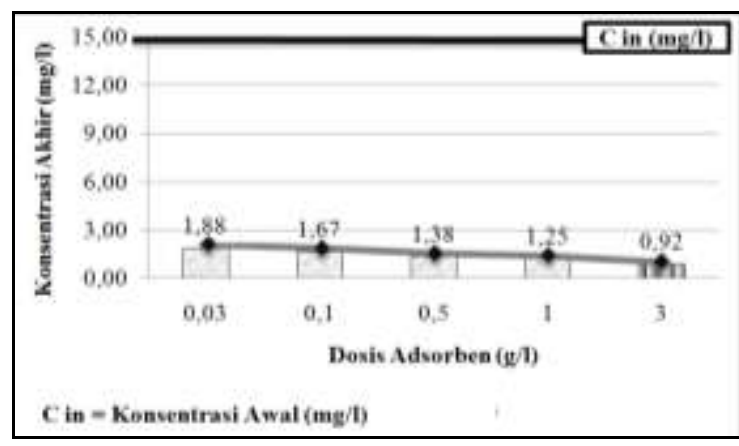

Gambar 3. Konsentrasi Akhir Fe Pada Variasi Dosis 


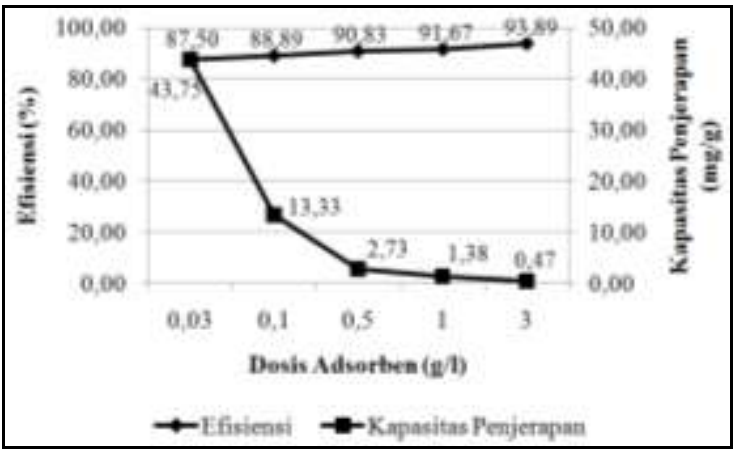

Gambar 4. Efisiensi dan Kapasitas Penjerapan Fe Pada Variasi Dosis

Pada percobaan ini, dosis $0,03 \mathrm{~g} / \mathrm{l}$ dipilih sebagai dosis optimum untuk percobaan selanjutnya karena dengan penggunaan dosis yang kecil sudah diperoleh efisiensi sebesar $87,50 \%$ dengan kapasitas penjerapan 43,75 $\mathrm{mg} / \mathrm{g}$.

Dari hasil percobaan diperoleh bahwa, semakin besar dosis adsorben yang digunakan pada percobaan optimasi maka semakin kecil konsentrasi akhir dari logam $\mathrm{Fe}$ dalam larutan serta efisiensi penyisihan logam $\mathrm{Fe}$ semakin besar namum kapasitas penjerapan semakin kecil.

\section{Penentuan Waktu Kontak Optimum}

Variasi waktu kontak yaitu 0,5 jam, 1 jam, 1,5 jam, 2 jam dan 2,5 jam dengan menggunakan diameter adsorben 210-300 $\mu \mathrm{m}, \mathrm{pH}$ adsorbat optimum yaitu $\mathrm{pH} 4$ dan dosis adsorben optimum yaitu 0,03 g/L. Hasil percobaan optimasi untuk parameter waktu kontak dapat dilihat pada Gambar 5 dan Gambar 6.

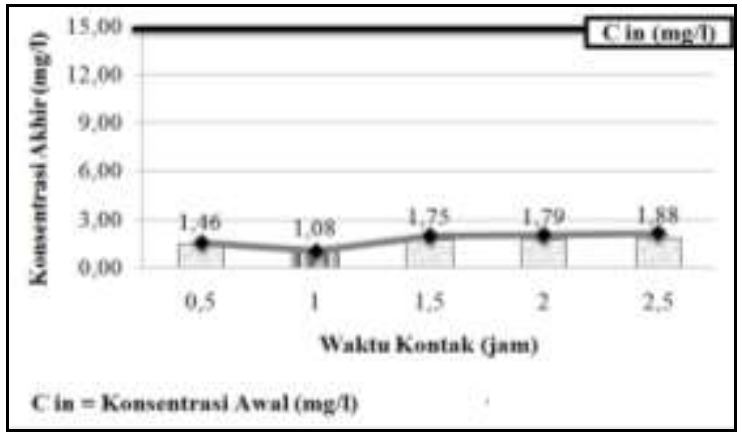

Gambar 5. Konsentrasi Akhir Fe Pada Variasi Waktu Kontak

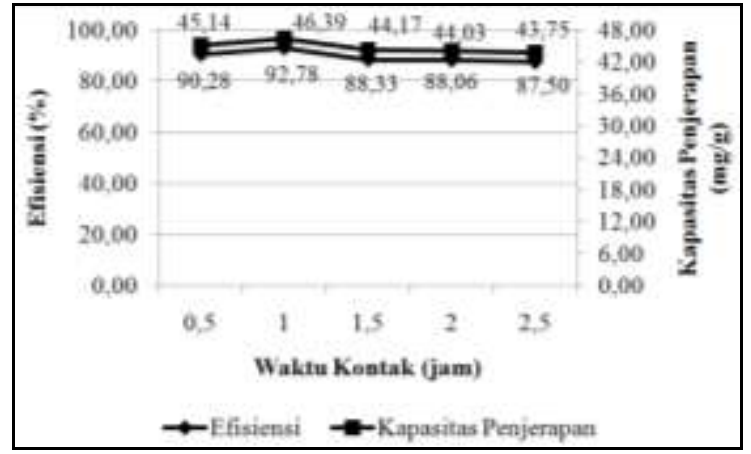

Gambar 6. Efisiensi dan Kapasitas Penjerapan Fe Pada Variasi Waktu Kontak

Penurunan konsentrasi logam $\mathrm{Fe}$ terbesar terjadi pada waktu kontak 1 jam yaitu dari konsentrasi awal $15 \mathrm{mg} / \mathrm{l}$ turun menjadi 1,08 $\mathrm{mg} / \mathrm{l}$ dengan efisiensi sebesar $92,78 \%$ dan kapasitas penjerapan $46,39 \mathrm{mg} / \mathrm{g}$.

Berdasarkan hasil percobaan kondisi optimum diperoleh pada waktu kontak 1 jam, kondisi ini sesuai dengan pernyataan Aima (2013), bahwa pada waktu kontak 1 jam masih terdapat banyak rongga kosong pada permukaan adsorben sehingga kapasitas penjerapan meningkat.

\section{Penentuan Diameter Adsorben Optimum}

Variasi diameter adsorben yaitu $<149 \mu \mathrm{m}$, 149-210 $\mu \mathrm{m}, 210-300 \mu \mathrm{m}, 300-600 \mu \mathrm{m}$ dan 600-710 $\mu \mathrm{m}$ dengan menggunakan kondisi optimum dari parameter lainnya yang telah diperoleh sebelumnya, yaitu $\mathrm{pH}$ adsorbat 4 , dosis adsorben $3 \mathrm{~g} / \mathrm{L}$ dan waktu kontak 0,5 jam. Hasil percobaan optimasi diameter adsorben dapat dilihat pada Gambar 7 dan Gambar 8.

Penurunan konsentrasi logam $\mathrm{Fe}$ terbesar terjadi pada diameter adsorben < $149 \mu \mathrm{m}$ yaitu dari konsentrasi awal $15 \mathrm{mg} / \mathrm{l}$ turun menjadi $1,21 \mathrm{mg} / \mathrm{l}$ dengan efisiensi sebesar 91,94\% dan kapasitas penjerapan 45,97 $\mathrm{mg} / \mathrm{g}$.

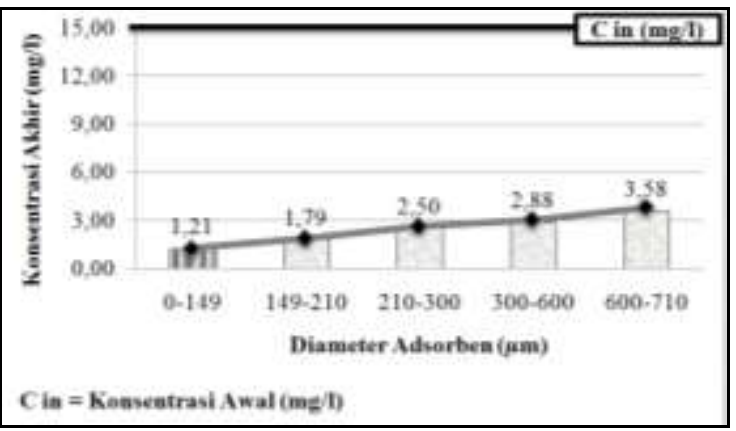


Gambar 7. Konsentrasi Akhir Fe Pada Variasi Diameter

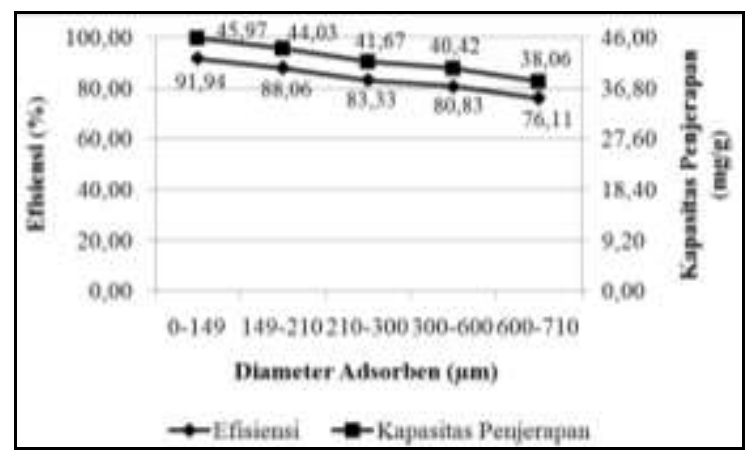

Gambar 8. Efisiensi dan Kapasitas

Penjerapan Fe Pada Variasi Diameter

Dari hasil percobaan diperoleh bahwa, diameter terkecil dari variasi yaitu $<149 \mu \mathrm{m}$ adalah diameter optimum. Hal tersebut sesuai dengan pernyataan Wibowo (2013) bahwa, semakin kecil ukuran variasi (diameter) batu apung menyebabkan meningkatnya kemampuan batu apung dalam proses penjerapan logam dalam air.

\section{Percobaan Optimasi pada konsentrasi Fe berbeda Pada Larutan Artifisial}

Pada percobaan optimasi pada konsentrasi $\mathrm{Fe}$ berbeda dilakukan variasi ph dan konsentrasi. Kondisi optimum dosis adsorben, waktu kontak dan diameter adsorben pada optimasi pada konsentrasi $\mathrm{Fe}$ samadigunakan sebagai parameter konstan. Hasil dari optimasi pada konsentrasi $\mathrm{Fe}$ berbeda dapat dilihat pada Gambar 9 dan Gambar 10.

Efisiensi penyisihan dan kapasitas penjerapan pada konsentrasi adsorbat 15 $\mathrm{mg} / \mathrm{l}$ dan $20 \mathrm{mg} / \mathrm{l}$ hampir sama oleh karena itu pada grafik terlihat berhimpit.

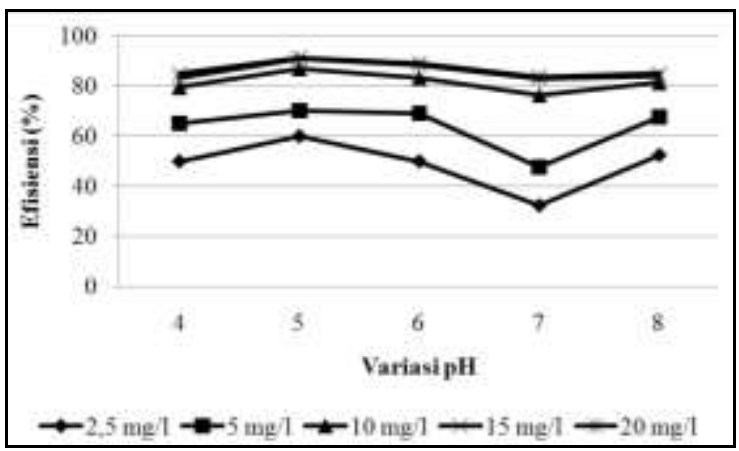

Gambar 9. Efisiensi Penyisihan Fe Pada Percobaan Optimasi pada konsentrasi Fe berbeda

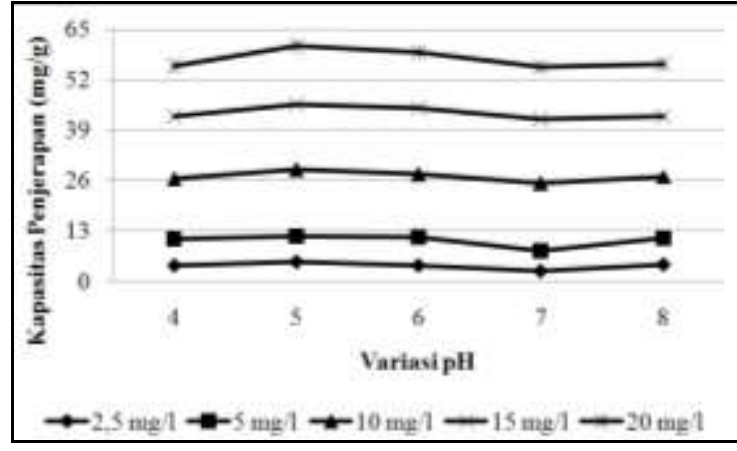

Gambar 10. Kapasitas Penjerapan Fe Pada Percobaan Optimasi pada konsentrasi Fe berbeda

Efisiensi penyisihan terbesar terjadi pada $\mathrm{pH}$ 5 dengan konsentrasi adsorbat $15 \mathrm{mg} / \mathrm{l}$ yaitu 91,25\% sedangkan kapasitas penjerapan terbesar terjadi pada $\mathrm{pH} 5$ dengan konsentasi adsorbat $20 \mathrm{mg} / \mathrm{l}$ yaitu $60,63 \mathrm{mg} / \mathrm{g}$.

Dari hasil percobaan dapat disimpulkan bahwa semakin besar konsentrasi logam $\mathrm{Fe}$ yang terdapat dalam larutan maka efisiensi akan semakin besar karena pada konsentrasi adsorbat $2,5 \mathrm{mg} / \mathrm{l} \quad-\quad 15 \mathrm{mg} / \mathrm{l}$ terjadi peningkatan efisiensi, namun terjadi penurunan efisiensi pada konsentrasi 20 $\mathrm{mg} / \mathrm{l}$. Kondisi tersebut sesuai dengan pernyataan Khairi (2004) bahwa, semakin tinggi konsentrasi Fe, maka jumlah Fe yang teradsorpsi dan efisiensi penyisihannya juga semakin besar tetapi pada konsestrasi $\mathrm{Fe}$ yang lebih dari kondisi setimbang, jumlah Fe yang teradsorp akan menurun.

$\mathrm{pH}$ optimum yang diperoleh pada percobaan adalah pH 5 (asam). Menurut Aima (2013), pada $\mathrm{pH}$ 4-6 (asam) adsorpsi logam Fe semakin besar disebabkan daya serap adsorben meningkat sedangkan pada $\mathrm{pH}$ 6-8 (basa) terjadi penurunan penjerapan karena mulai terbentuk endapan yang menganggu proses adsorpsi.

\section{Percobaan Pada Sampel Air Tanah}

Kondisi optimum yang diperoleh dari percobaan optimasi kemudian dicobakan terhadap sampel air Sumur Perumahan Lubuk Kilangan. Kondisi optimum yang digunakan adalah dosis adsorben $0,03 \mathrm{~g} / \mathrm{L}$, waktu kontak selama 1 jam, diameter adsorben < $149 \mu \mathrm{m}, \mathrm{pH}$ adsorbat 5 dan konsentrasi adsorbat $15 \mathrm{mg} / \mathrm{l}$. Hasil percobaan pada sampel dapat dilihat pada Gambar 11. 


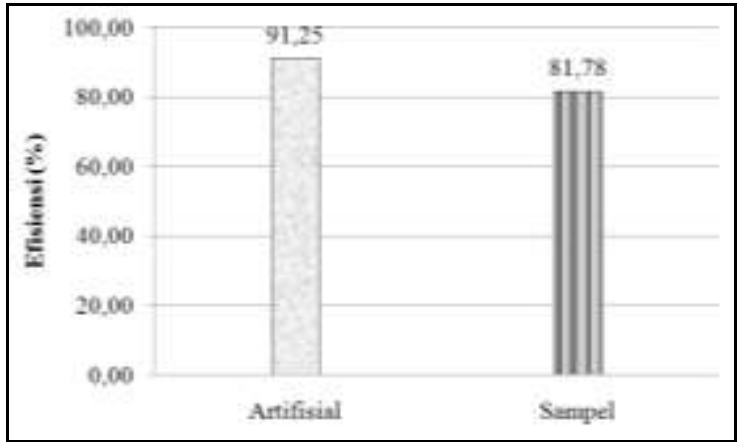

Gambar 11. Perbandingan Efisiensi Penyisihan Fe pada Larutan Artifisial dan Sampel

Pada larutan artifisial efisiensi penyisihan logam Fe sebesar 91,25\% sedangkan pada sampel efisiensi penyisihan sebesar $81,78 \%$. Perbedaan efisiensi tersebut terjadi karena pada sampel terdapat logam-logam lain yang mempengaruhi proses adsorpsi logam $\mathrm{Fe}$ yaitu logam $\mathrm{Zn}$, logam $\mathrm{Cu}$, logam $\mathrm{Mn}$ dan logam lainnya.

Daya afinitas logam $\mathrm{Fe}$ lebih kecil dibandingkan logam $\mathrm{Zn}$ dan $\mathrm{Cu}$ namun lebih besar dari $\mathrm{Mn}$ oleh karena itu terjadi kompetisi antar logam yang menyebabkan penjerapan logam $\mathrm{Fe}$ terganggu. Hal ini sesuai dengan deret afinitas logam menurut Zakaria (2011) yaitu $\mathrm{Al}^{3+}>\mathrm{Pb}^{2+}>\mathrm{Cd}^{2+}>$ $\mathrm{Zn}^{2+}>\mathrm{Cu}^{2+}>\mathrm{Fe}^{2+}>\mathrm{Mn}^{2+}>\mathrm{Ca}^{2+}>\mathrm{Mg}^{2+}>\mathrm{K}^{+}$ $>\mathrm{NH}^{4+}>\mathrm{H}^{+}$.

Beberapa penelitian menyebutkan bahwa efisiensi penyisihan pada sampel selalu lebih kecil dibandingkan dengan efisiensi pada larutan artifisial diantaranya efisiensi penyisihan minyak dan lemak pada limbah hotel sebesar 70,44\% sedangkan pada artifisial sebesar $80 \%$ (Notrilauvia, 2012) dan efisiensi penyihan logam timbal $(\mathrm{Pb})$ dari limbah cair percetakan koran sebesar $81,25 \%$ sedangkan pada larutan artifisial sebesar 81,25\% (Marjid, 2011).

Berdasarkan hasil percobaan dapat disimpulkan bahwasanya penggunaan batu apung sebagai adsorben memberikan hasil yang cukup baik dalam proses penyisihan logam $\mathrm{Fe}$.

\section{Penentuan Persamaan Isoterm}

Kurva persamaan isoterm Langmuir dan persamaan isoterm Freundlich dibuat dengan menggunakan kondisi optimum pada konsentrasi adsorbat pada setiap variasi $\mathrm{pH}$, yaitu konsentrasi adsorbat $15 \mathrm{mg} / \mathrm{l}$. Untuk lebih jelasnya kurva masing-masing persamaan isoterm dapat dilihat pada Gambar 12 dan Gambar 13.

Persamaan isoterm Langmuir merupakan isoterm yang cocok sebagai model kesetimbangan untuk adsorpsi logam $\mathrm{Fe}$ dengan adsorben batu apung karena nilai $\mathrm{R}^{2}$ yang paling mendekati 1 yaitu 0,999 dengan kapasitas adsorpsi maksimum (a) sebesar $38,46 \mathrm{mg} / \mathrm{g}$ dan konstanta kesetimbangan (b) sebesar $-5,20$.

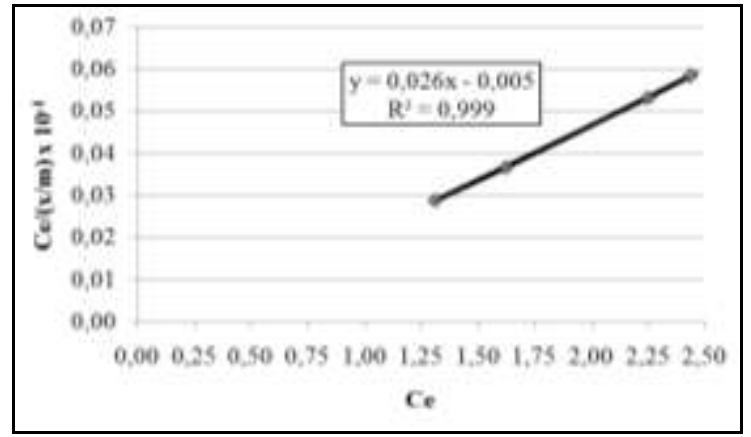

Gambar 12. Isoterm Langmuir Untuk Adsorpsi Logam Fe Dengan Adsorben Batu

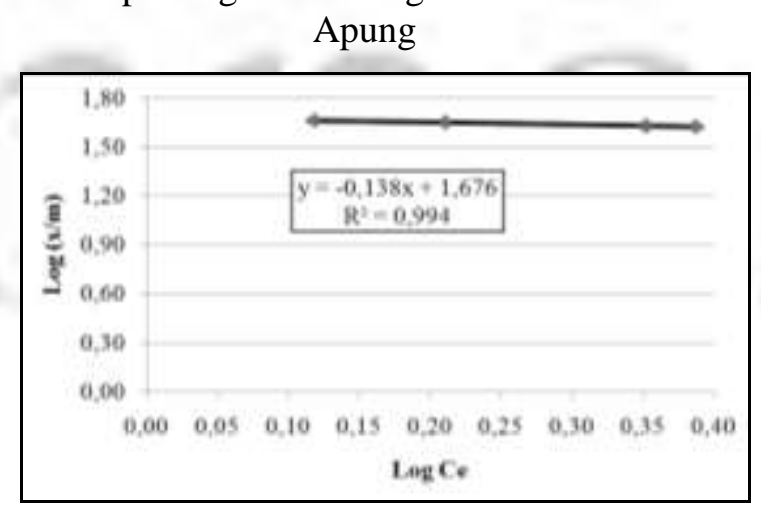

Gambar 13. Isoterm Freundlich Untuk Adsorpsi Logam Fe Dengan Adsorben Batu Apung

\section{SIMPULAN}

Dari hasil percobaan mengenai kemampuan batu apung sebagai adsorben dalam penyisihan logam Fe air Sumur Perumahn Bandar Buat dapat disimpulkan sebagai berikut:

Kondisi optimum penyisihan logam $\mathrm{Fe}$ pada larutan artifisial adalah pada dosis adsorben $0,03 \mathrm{~g} / \mathrm{l}$, waktu kontak 1 jam, diameter adsorben $<149 \mu \mathrm{m}, \mathrm{pH}$ adsorbat 5 dan konsentrasi adsorbat $15 \mathrm{mg} / \mathrm{l}$ dengan efisiensi penyisihan $91,25 \%$. Penyisihan logam Fe pada sampel adalah 81,78\%. Perbedaan efisiensi penyisihan pada larutan 
artifisial dan sampel dikarenakan pada sampel terdapat logam $\mathrm{Zn}, \mathrm{Cu}, \mathrm{Mn}$ dan lainnya yang memmpengaruhi proses adsorpsi logam Fe.

Persamaan isoterm Langmuir terpilih sebagai model kesetimbangan yang cocok dengan proses adsorpsi logam $\mathrm{Fe}$ dengan adsorben batu apung karena nilai $\mathrm{R}^{2}$ yang paling mendekati 1 yaitu 0,999 .

\section{DAFTAR PUSTAKA}

Aima, S., Zahrina, I dan Zultiniar. 2012. Adsorpsi Logam Fe dengan Zeolit 4A yang Disintesis dari Fly Ash Sawit. Jurusan Teknik Kimia. Fakultas Teknik Universitas Riau

Atkins, P.W. 1999. Kimia Fisika Jilid II. Oxford University

Effendi, H. 2003. Telaah Kualitas Air Bagi Pengelolaan Sumber Daya dan Lingkungan Perairan. Yokyakarta :Kanisius.

Endahwati, L. 2011. Kombinasi Proses Aerasi, Adsorpsi dan Filtrasi Pada Pengolahan Air Limbah Industri Perikanan. Jawa Timur : Fakultas Teknologi Industri . UPN Veteran

Heidari, M., Moattar, F., Naseri, S., Samadi, M.T. dan Khorasani, N. 2011. Evaluation of Aluminium Coated Pumice As A Potensial Arsenic (v) Adsorbent From Water Resources. Departement of Environmental Science. Faculty of Environment And Energy. Islamic Azad University. Tehran. Iran
Joko, T. 2010. Unit Produksi Dalam Sistem Penyediaan Air Minum. Graha Ilmu : Yogyakarta

Khairi, Rahmi dan Mawaddah. 2004. Uji Daya Serap Kristobalit Alam Jaboi Sabang Nangroe Aceh Darussalam Terhadap Ion Logam $\mathrm{Fe}^{3+}$. Jurusan Kima FMIPA Universitas Syiah Kuala

Kitis, M., Kaplan, S.S., Karakaya, E., Yigit, N.O dan Civelekoglu, G. 2007. Adsoption of Natural Organic Matter From Waters By Iron Coated Pumice. Department of Environmental Engineering Suleyman Demirel University : Turkey

Marjid, R.P. 2011. Kemampuan Kitosan Limbah Cangkang Udang Sebagai Resin Pengikat Logam Timbal (Pb). Jurusan Teknik Lingkungan Universitas Andalas

Notrilauvia, N. 2012. Penyisihan Minyak dan Lemak Limbah Cair Hotel Menggunakan Serbuk Kulit Jagung. Jurusan Teknik Lingkungan Universitas Andalas

Somerville, R. 2007. Low-Cost Adsorption Materials for Removal of Metals From Contaminated Water. TRITALWR Master Thesis. KTH Architecture and the Built Environment.

Wibowo, A.Y dan Putra, A. 2013. Pengaruh Ukuran Partikel Batu Apung Terhadap Kemampuan Serapan Cairan Limbah Logam Berat. Jurusan Fisika. FMIPA universitas Andalas

Zakaria, A. 2011. Adsorpsi Cu (II) Menggunakan Zeolit Sintetis dari Abu Terbang Batu Bara. Institut Pertanian Bogor 